\title{
Notas para el estudio de las rebeliones indígenas a fines del período colonial en la frontera tucumana del Chaco $(\mathbf{1 7 8 1})^{1}$
}

\author{
Enrique Normando Cruz \\ CONICET, Argentina
}

En 1781 en la frontera tucumana del Chaco de la ciudad de Jujuy, al norte del virreinato del Río de la Plata, se desarrolla una rebelión indígena que se asocia con la "Gran Rebelión Andina" de Túpac Amaru en Perú y los Katari de La Paz y Chayanta. En el presente artículo se revisan, agrupan y discuten a partir de dos hipótesis los trabajos que existen sobre la rebelión, considerándose en primer lugar aquellos que proponen que este movimiento consiste en una "repercusión local" de las rebeliones cuzqueña y paceña (especialmente de la primera); y posteriormente los textos que concuerdan en la calificación de la rebelión, pero disienten en las causas. Esto nos permitirá precisar los presupuestos teóricos, bibliografía y fuentes utilizadas en las observaciones pertinentes. Al final se proponen unas conjeturas para el estudio de las rebeliones indígenas en espacios fronterizos a finales del período colonial.

Palabras Clave: Rebeliones, tobas, frontera del Chaco, Jujuy.

In 1781 in the tucumana border of the Chaco of the city of Jujuy to the north of the virreinato of the River of the Silver, is developed an indigenous rebellion that is associated with the "Great Andean Rebellion" of Tupac Amaru in Peru and the Katari of La Paz and Chayanta. In this note they are reviewed, they group and they discuss in two hypotheses all the works that on the rebellion exist, considering first those that propose that the rebellion is a "local repercussion" of the rebellions cuzqueña and paceña (specially of the first); and soon the works that agree in the qualification of the rebellion, but dissent in the causes. The historiographical analysis appears in two hypotheses to need the theoretical budgets, bibliography and sources used in the pertinent observations, setting out in the end conjectures for the study of the indigenous rebellions by the end of the colonial period in border areas.

KEYwoRDs: Rebellion, tobas, border of the Chaco, Jujuy.

En la frontera del Chaco de Jujuy, al norte del virreinato del Río de la Plata (Intendencia de Salta del Tucumán), desde marzo a abril de 1781 se

1 Este texto ha sido realizado gracias a una Beca de Residencia y Estudio en la Escuela de Estudios Hispano-Americanos de Sevilla en noviembre del 2003. También agradezco a los evaluadores anónimos del Anuario de Estudios Americanos las correcciones y críticas realizadas. 
desarrolla una rebelión fronteriza que la historiografía considera que excede el espacio local y se amplia a la frontera tucumana del Chaco (jurisdicciones fronterizas de Salta, Tucumán y Santiago del Estero) y, de acuerdo a la vinculación mayor o menor que establecen con los alzamientos Tupamarista y Katarista, también consideran al espacio andino altoperuano. De la misma manera se amplía el lapso temporal de esa rebelión a las Reformas Borbónicas, y se la relaciona en sus orígenes con la guerra fronteriza acaecida en el Chaco durante los siglos XVII y XVIII. Revisaremos aquí los trabajos sobre el tema atendiendo a dos hipótesis. Se considerarán primero los que proponen que la rebelión desarrollada alrededor de la reducción de San Ignacio (fundada en 1756 y puesta en manos jesuitas y luego franciscanas) es una "repercusión local" de las rebeliones arriba citadas, cuzqueña y paceña (especialmente de la primera), destacando que las causas, motivaciones y el mismo desarrollo ya se explican en la "Gran Rebelión Andina": la explotación española de los indígenas y las ansias de independencia criolla que dan lugar a un movimiento que lucha primero por la independencia y libertad criolla, luego indígena, y por último social en general. En segundo lugar, serán considerados otros trabajos que están de acuerdo con la calificación de la rebelión, pero disienten en las causas, argumentando que lo que pasó en la frontera del Chaco de Jujuy no es una "repercusión" de los planteamientos reformistas o revolucionarios altoperuanos de 1780, sino que tiene que ver con el ciclo de "resistencias" fronterizas e indígenas de todo el período colonial y en especial del siglo XVIII.

\section{La rebelión toba de 1781 como repercusión de la gran rebelión andina tupamarista}

La primera explicación historiográfica de lo acaecido en 1781 en la frontera tucumana del Chaco considera que se trata de una "repercusión tupamarista". ${ }^{2}$ El estudio señala que la rebelión tiene un liderazgo bien definido: "un criollo, José Quiroga, se dirigió a la reducción de indios tobas nombrada San Ignacio y allí convenció a esos naturales de que "ya tenían rey inca" por lo que deseaba que le ayudasen a destruir a todos los españo-

2 Este estudio es el primero del tema y de él se derivan los siguientes, que siguen su interpretación, la cuestionan o plantean otra. Acevedo, Edberto O.: La intendencia de Salta del Tucumán en el Virreinato del Río de La Plata, Universidad Nacional de Córdoba, Facultad de Filosofía y Letras, Mendoza, 1965. 
les"; ${ }^{3}$ además se estima que la secuencia de la rebelión es la siguiente: primero esos indígenas se rebelan y "cometieron distintas tropelías", más tarde atacan los fuertes que protegen la citada reducción, se dirigen al del Río Negro y cuando están a punto de tomarlo, un destacamento de veteranos despachados por el virrey de Buenos Aires levanta el sitio y los dispersa. A continuación, los rebeldes son castigados de distinta manera: a los indígenas matacos (wichies), que "también se habían alzado en conexión con los tobas, y persistían en sus atropellos", se les reprime "tomando setenta y cinco indios mayores, doce muchachos, una muchacha y una anciana que traían por adivina" y se les pasa por las armas, con excepción de los niños, y "dejándolos pendientes de los árboles para terror de los demás". Luego se persigue, apresa y escarmienta a los cabecillas criollos y finalmente, se muestra cautela en la represión de los tobas, pues, aunque vuelven a la reducción y no parecen tener "ánimo de ocasionar nuevas inquietudes", de acuerdo con el gobernador del Tucumán Andrés Mestre tienen "natural inclinación a la libertad y el simulado odio que nos profesan no les permite segura reconciliación, ya impresionados del eco que les ha hecho el nombre de Tupaamaro, o persuadidos de que el perdón que se les ofreció fuese cauteloso, les hizo desamparar segunda vez la reducción y retirarse a los montes". La inquietud del gobernante parece tener fundamento, porque la rebelión continúa pero en esta ocasión localizada en la parte feraz de la frontera, en el paraje de Caimancito, y comprende exclusivamente en la composición y liderazgo a los indígenas: "se tuvo la certidumbre que los matacos se habían alzado y se dirigían al fuerte del Río Negro... por lo que las autoridades calculan que se volvería a armar la alianza, pero esta vez únicamente indígena".

De manera similar se produce el desarrollo de la rebelión de los campesinos kollas de la Puna de Jujuy, sólo que la relación altoperuana es más bien con la rebelión de "Túpac Katari, que mantenía un prolongado sitio a la ciudad de La Paz". ${ }^{4}$ En todo caso, ambos movimientos son reprimidos sin demasiado esfuerzo por las autoridades, sin embargo su extensión espacial y social demostraría la endeble y a la vez opresiva dominación hispánica en Jujuy.

En la rebelión los criollos son presentados como los protagonistas, porque la incitan, lideran y son reprimidos y escarmentados. Respecto a la

3 Ibídem, pág. 40.

4 Ibídem, págs. 41-44. 
alianza entre los indígenas tobas y wichies, corresponde sólo al concierto en el ataque a los fuertes y reducción de la frontera. Con relación a las causas, para el autor son "la difusión de la rebelión de Túpac Amaru, la constitutiva inestabilidad indígena, su aversión al sistema político-social español...” y otras locales: “ en el caso concreto del Tucumán, había motivos sociales de diferenciación — como la situación de las castas, prontas para buscar su libertad e independencia y, sobre todo, la de aquellas gentes que ocupaban el último estrado social, ignorantes, insubordinados o ociosasque hicieron posible que ocurriesen los sucesos narrados". ${ }^{5}$

Otra interpretación histórica de la rebelión la considera como una "Rebelión de Túpac Amaru en el actual territorio Argentino", debido a que se identifica y analiza como "ecos de las turbulencias del Perú" una serie de hechos en los distritos rioplatenses de Buenos Aires, Córdoba, La Rioja, Mendoza, Tucumán, Salta y Jujuy; aquí sólo se considera como rebelión la de Jujuy, que el autor denomina "La atracción del maldito nombre de Túpac Amaru en Salta y Jujuy". ${ }^{6}$ A diferencia del estudio anterior, se unifica el movimiento de la frontera del Chaco con los hechos de la Puna de Jujuy, y se sostiene que lo determinante en la resistencia de los indígenas de las tierras altas y bajas es que "los indios y la plebe están impresionados del eco que les ha hecho el nombre de Tupaamaro". También se destaca que los rebeldes jujeños son capitaneados por el mestizo José Quiroga: "intérprete en la reducción de San Ignacio de indios tobas, la única estable y sólida que tuvieron los jesuitas en la provincia de Jujuy, aprovechó sus relaciones con estos indios y con los indígenas del Chaco no reducidos, donde había servido como soldado, para organizar en febrero de 1781, un vasto alzamiento tupamarista". 7 Asimismo señala que la rebelión es el resultado de la alianza entre la plebe urbana y rural, mestiza y criolla que vive en la frontera de Jujuy, con los indígenas reducidos y no reducidos: "aunada toda la gente de Perico, Isla y Carril con los indios tobas". ${ }^{8}$

El tercer trabajo consiste en un ensayo específico sobre la rebelión toba de 1781 bajo la hipótesis general de las "repercusiones tupamaristas". En la descripción del escenario geográfico y social se destacan las cualida-

5 Ibídem, pág. 45.

6 Lewin, Boleslao: La rebelión de Túpac Amaru y los orígenes de la Independencia Hispanoamericana, Sociedad Editora Latinoamericana, Buenos Aires, 1967 (1 Edición 1943), pág. 581.

7 Ibídem, págs. 581-582.

8 Ibídem, págs. 583-594. 
des guerreras de los indígenas chaqueños y la dificultad para identificarlos pues: "De la voz del primitivo morador de estas tierras sólo quedan vestigios, restos posibles de rastrear en las crónicas, diarios de viaje y otros documentos del período". ${ }^{9}$ Se tiene en cuenta la interpretación de Acevedo acerca de las "repercusiones en el Tucumán" de la rebelión de Túpac Amaru, al igual que la división realizada por dicho autor en dos etapas, y se identifica que "el principal agente de la sublevación era el criollo José Quiroga, soldado del fuerte del Río Negro". A continuación intercala los acontecimientos que se consideran como parte de la rebelión en la Puna de Jujuy, específicamente los sucesos desarrollados en las propiedades del marqués del Valle de Tojo y, finalmente, vuelve sobre los acontecimientos en el Chaco y con base en un documento reproducido por Lewin, destaca los "alcances de la sublevación y los contactos multiétnicos de la misma; Jossef Quiroga, criollo; Antonio Umacata, indio ladino; Gregorio Juárez, criollo de Santiago del Estero; Basilio Eraso, natural de Estarca, de la provincia de Chichas, mestizo amulatado; y Jossef Domingo Morales, alias Rojas, criollo"..$^{10}$ Para la autora, la rebelión de los tobas y campesinos indígenas de la Puna de Jujuy tiene claros antecedentes Tupamaristas y existe una alianza "multiétnica" entre indígenas del Chaco, criollos y gente mezclada racialmente: "el conflicto de las castas predispuestas a buscar su libertad, se veía agravado por la situación de las reducciones fronterizas luego de la expulsión de los jesuitas"."

Las fuentes y bibliografía de los trabajos de Acevedo y Lewin son relatos de viajeros, crónicas misioneras y colecciones documentales,${ }^{12}$ pero el texto de Poderti, además de tener en cuenta una parte de la bibliografía considerada por los otros estudios, toma como fuentes las citas documentales - tanto en el cuerpo de texto como en las notas al pie de página- de los dos trabajos anteriores e incorpora estudios sobre la economía de las

9 Poderti, Alicia: Palabra e historia en los Andes. La rebelión del Inca Túpac Amaru y el Noroeste Argentino, Ediciones Corregidor, Buenos Aires, 1997, pág. 22.

10 Ibídem, págs. 30-32.

11 Ibídem, pág. 40.

12 Por ejemplo Tamajuncosa, Antonio: "Descripción de las misiones al cargo del Colegio de Nuestra Señora de los Angeles de la villa de Tarija", en De Angelis, Pedro: Colección de obras y documentos relativos a la historia antigua y moderna de las provincias del Río de la Plata, Librería Nacional de J. Lajaune, Buenos Aires, 1910. Lizondo Borda, Manuel: Historia del Tucumán (siglos XVII y XVIII), Universidad Nacional de Tucumán, Tucumán, 1941. Tommasini, Gabriel: La civilización cristiana del Chaco (1554-1810), 2 tomos, Librería Santa Catalina, Buenos Aires, 1937. 
sociedades indígenas y la propiedad de la tierra en la frontera del $\mathrm{Chaco}^{13}$ y distintos trabajos sobre las rebeliones andinas. ${ }^{14}$

En cuanto a las fuentes documentales, Acevedo remite al principal documento elaborado por las autoridades locales del Cabildo de Jujuy sobre la rebelión, ${ }^{15}$ y considera la documentación del Archivo General de la Nación Argentina. El estudio de Lewin, como el de Poderti, se refiere a los documentos e interpretaciones del historiador citado más arriba, incorporando el primero un documento publicado por la Revista del Archivo de Santiago del Estero que también reproduce la segunda, quien además agrega un documento de la visita episcopal a Salta de 1782 ó 1783. Una fuente de todos estos textos la constituyen los documentos sobre la rebelión de Túpac Amaru publicados por De Angelis en 1910, que se centran especialmente en la correspondencia de las autoridades locales de Jujuy con la gobernación del Tucumán. ${ }^{16}$

Las consecuencias que se observan son que el liderazgo en la rebelión es "criollo", que hay acuerdo interétnico entre las tribus tobas y parcialidades indígenas del Chaco pero sólo a los efectos de la rebelión, y que las causas de ésta son: la "difusión de la rebelión de Túpac Amaru" que como "ecos" llegan al Río de la Plata, "Noroeste Argentino" y frontera jujeña del Chaco; la inestabilidad resultante de una sociedad de castas y la "belicosidad" de los indígenas chaqueños, de lo que se deriva la idea de que existe una alianza entre la "plebe ociosa y vagabunda" y los indígenas del Chaco. También se unifica la rebelión de esos indígenas chaqueños con las revueltas campesinas de la Puna y se señala que la apelación a "que tenían un Rey Inca" anuncia la emancipación de los españoles y la constitución de un gobierno propio, primero de los indígenas y luego también de la plebe, como un antecedente de la emancipación independentista de 1810.

13 Santamaría, Daniel: "Población y economía interna de las poblaciones aborígenes del Chaco en el siglo XVIII", Andes, 9, Salta, 1998. Mata de López, Sara: "Estructura agraria. La propiedad de la tierra en el valle de Lerma, valle Calchaquí y la frontera este (1750-1800)", Andes, 1, Salta, 1989.

14 Valcárcel, Daniel: Rebeliones Indígenas, PTCM, Lima, 1946. O’Phelan Godoy, Scarlett: Un siglo de rebeliones anticoloniales. Perú y Bolivia 1700-1783, Centro de Estudios Regionales Andinos Bartolomé de las Casas, Cusco, 1988. Glave, Luis Miguel: La rebelión de Túpac Amaru, Centro de Estudios Regionales Andinos Bartolomé de las Casas, Cusco, 1982.

15 Archivo General de Indias (AGI), Buenos Aires, 143.

16 "Documentos para la historia de la sublevación de José Gabriel de Tupac-Amaru cacique de la provincia de Tinta, en el Perú", en De Angelis, Pedro: Colección de obras y documentos... 


\section{La rebelión toba de 1781 como adaptación en resistencia}

El estudio de la frontera tucumana del Chaco cuenta con dos nuevos textos que la examinan a partir de la hipótesis de la "adaptación en resistencia", relacionándola con la coyuntura de creación de la Intendencia de Salta del Tucumán y con el ciclo de guerra fronteriza de todo el siglo XVIII y más hacia atrás.

Al considerar la rebelión, se la califica como una "gran sublevación Toba", conectada con la creación de las Intendencias de Salta y Córdoba, y destacándose como un aspecto explicativo el carácter guerrero, igualitario y belicoso de los indígenas chaqueños a partir de los primeros años de la conquista y la fundación de ciudades desde el siglo XVI hasta el XVIII. ${ }^{17}$ En el análisis de las políticas de conquista y colonización del Chaco, se señala que en la segunda mitad del siglo XVIII y ante el panorama "secular de guerra" hay una especie de "plan para atraerlos a la obediencia y convertirlos a la religión", que tiene amplia "repercusión en el ideario de la Junta Reduccional que se celebró en San Miguel de Tucumán en 1779”, en la que se discute acerca de la conveniencia de establecer fuertes y reducciones para llevar la frontera del Chaco tucumano hasta el río Bermejo. Esta idea, que parte del contexto local para estudiar lo que el autor llama "gran sublevación Toba", destaca que para lograr la conquista del Chaco y la ampliación de la frontera hasta el río Bermejo, se emplearon los presidios y las misiones para crear un "cordón defensivo" y, a la vez, controlar más directamente a la población indígena y proteger las nuevas estancias que habían sobrepasado la línea defensiva de los presidios. Proyecto que, aunque tiene oposición, termina por imponerse y se inicia así el desarrollo de una política para "comprar la paz", ${ }^{18}$ que se detiene porque la sublevación de Túpac Amaru se "extendió rápidamente y paralizó el comercio de la gobernación del Tucumán con el norte", reconociendo en los descalabros comerciales producidos por la rebelión, las relaciones tupamaristas, pero negando otra identificación entre los sucesos peruanos y los chaqueños. Además de cuestionar las vinculaciones tupamaristas, se discute la hipótesis derivada de que una de las causas locales reside en el desgobierno pos-

17 Gullón Abao, Alberto: La frontera del Chaco en la Gobernación del Tucumán (1750-1810), Universidad de Cádiz, Cádiz, 1993, págs. 109-104.

18 Ibídem, págs. 110-113. 
terior a la expulsión jesuítica, pues se había paliado por la comisión del teniente Tomás Pacheco a la reducción de San Ignacio, que restaura y resuelve "el problema del sustento". ${ }^{19}$

Para este estudio, respecto a la causa principal del alzamiento "puede deducirse que las bases de su forma de vida (refiriéndose a los tobas) persistían, así como una resistencia sistemática a la llamada vida "civilizada" que los españoles les pretendían imponer", y los tobas y mestizos se levantan en armas contra la autoridad por el liderazgo criollo, que aprovecha la circunstancia de una sublevación regional y el malestar local: "José Quiroga, conocedor de los acontecimientos altoperuanos, vio en la reducción una fuerza de choque que, junto con los sectores menos favorecidos, sería capaz de desbancar el orden establecido, y debió convencer a los tobas de las ventajas que les otorgaba el nuevo "Rey Inga", aprovechando la fragilidad del status quo que proporcionaban las reducciones y la belicosidad intrínseca de esta nación; los incitó a un levantamiento general con otras naciones del interior". ${ }^{20}$

Un aspecto que destaca este texto es que reconoce e identifica, en general, la colonización altoperuana de la segunda mitad del siglo XVIII con la frontera jujeña del Chaco, lo que en parte explicaría la "sublevación del norte del Tucumán, no sólo por las reivindicaciones sociales y económicas, sino también por razones culturales y vínculos directos con la zona alto peruana". Así, para el autor: "Estamos, pues ante una rebelión dirigida por mestizos, que tenían una vinculación más o menos directa con el Alto Perú, pero que vivían en la frontera jujeña, con problemas intrínsecos a la zona, y que usaron a los tobas, ofreciéndoles la posibilidad de liberarse del yugo español; ahora bien estos indígenas no tenían las mismas reivindicaciones que los dirigentes, pero sí coincidían en la necesidad de una transformación de la estructura dominante en ese momento, para lo cual era necesario destruir a los españoles". ${ }^{21}$ Finalmente, aunque la rebelión tiene en cuenta el nombre del "Inga" altoperuano, las motivaciones, causas y reivindicaciones son estrictamente locales y correspondientes a la realidad de "guerra" de la frontera chaqueña del Tucumán, y en la base de la adhesión de esos indígenas a la rebelión, está la belicosidad de los tobas y el "malestar" de los "sectores más desfavorecidos": inmigrantes altoperuanos, mezclados con la población criolla local de la frontera.

19 Ibídem, pág. 114.

20 Ibídem, pág. 115.

21 Ibídem, págs. 116-117. 
El último estudio a considerar sobre la rebelión juzga que la convocatoria regional rebelde de Túpac Amaru canalizó los deseos de "venganza toba y la insatisfacción de la plebe". ${ }^{22}$ En primer lugar, se define el territorio jujeño del Chaco como una "frontera de guerra", que genera un conflicto externo con los indígenas de esa zona, y otro interno en las ciudades coloniales entre "vecinos feudatarios vs. vecinos moradores, españoles ricos vs. españoles pobres y finalmente españoles nativos hacendados vs. españoles criollos mayordomos, capataces, peones y soldados". ${ }^{23}$ Tras destacar la particularidad de la guerra para explicar como se dan las relaciones sociales en la frontera del Chaco, y que la misma provoca una tensión en la sociedad hispánica del Tucumán, expone la metodología con la que encara la "reinterpretación": "El enfoque de este trabajo se alimenta de una perspectiva teórica que considera a los campesinos como continuos generadores de acciones políticas, aun en los períodos de aparente tranquilidad. Al poner en juego una variada gama de respuestas pacíficas, y ocasionalmente rebelión, los campesinos son capaces de acomodarse de la forma más exitosa posible a las situaciones que les plantea la sociedad global".$^{24} \mathrm{~A}$ partir de este planteamiento, se vincula la rebelión con la evolución histórica de conformación de la frontera oriental o tucumano-chaqueña y las distintas etapas de apropiación geográfica y expansión económica que aquél generó: tráfico de productos y gentes vinculados a los procesos de control de pisos ecológicos y luego, la resistencia y conformación desde muy temprano de un frente de conquista con el Chaco. ${ }^{25}$

De forma conjunta con el avance militar y reduccional hispánico, se da la marcha sobre las tierras de los indígenas chaqueños que resultó en "el despojo de sus fuentes de subsistencia y reproducción" y en un proceso de expansión sobre los valles subtropicales, a través de los repartimientos de grandes extensiones de tierra a los hispanos en compensación por los servicios militares en las campañas punitivas contra los chaqueños. ${ }^{26}$ Así se

22 Sánchez Bramdam, Sandra: “Se hace camino al andar”. Túpac Amaru en Jujuy: una reinterpretación, Tesis de Maestría, Santiago de Chile, 2002.

23 Ibídem, pág. 16.

24 Ibídem, pág. 18

25 "Ni Argañaráz (el titular de la fundación de la ciudad de Jujuy) ni sus sucesores pudieron conquistar a los "salvajes del Chaco". Este "frente bélico" que acompañó el nacimiento y la muerte del dominio español en la región del Tucumán, tuvo un peso fundamental en la política, en la economía y en las relaciones sociales de la jurisdicción de Jujuy; y en una ocasión su protagonismo "estremeció al entero virreinato del Río de la Plata”. Ibídem, págs. 45-51.

26 Ibídem, págs. 64-70. 
configura un panorama donde la política militar y colonizadora en el Chaco, de fundación y funcionamiento de fuertes, reducciones y haciendas, da lugar al malestar de los indígenas tobas de San Ignacio que: "se encontraban maltratados y presionados por doctrineros y comandantes, controlados y abandonados social, laboral y materialmente por el Estado, arrinconados y despojados de sus tierras por los avances sucesivos de las haciendas, pero todavía vinculados con su cultura y gente y siempre listos para conmocionar la Frontera". ${ }^{27}$

En base al contexto elaborado de la realidad de "guerra de frontera en el Chaco", un documento del Archivo local del Obispado (especie de probanza de méritos y servicios del comandante de armas de frontera Gregorio de Zegada), y la detección y análisis de un estado de "violencia registrada" y no registrada que pudo servir como "catalizador y catarsis a las sociedades indígenas y mestizas, es decir, como una forma de diluir, de transformar y, por qué no, de purgar y liberar su propia rebeldía frente a un orden de expoliación y dominación", se reinterpreta lo acaecido en la frontera jujeña del Chaco en 1781. Primero se cuestionan los orígenes tupamaristas, y que la rebelión más bien trató de aprovechar "la coyuntura de rebelión generalizada" para "vengar siglos de desmembramiento social, vejaciones, despojo y explotación", para "desafiar y alertar a un orden dominador que cada vez más los excluía y abandonaba", y para tratar de "controlar y porqué no manejar ese umbral social y económico", ese "otro mundo" que el conjunto de "desplazados había creado en la frontera". Y que, en todo caso, la referencia tupamarista de un "Rey Inca", sirvió para que la elite hispana afianzara su dominio social, político y, sobre todo, económico en el ámbito urbano, silenciara a "los disconformes de sectores menos favorecidos — blancos pobres y mestizos - y desplegara su poder ejemplarizador pero a la vez benevolente, sobre los indomables grupos de la frontera". Segundo, las acciones rebeldes presentan todas las características de los alzamientos indígenas tobas del Chaco desde el siglo XVII en adelante: alianza con matacos (wichies) no reducidos, formación guerrera en trozos, envío de espías a los fuertes y ciudades, utilización del monte como lugar de refugio y punto de encuentro, etc. Todo ello considerando que tales alzamientos, "cuanto más graves fueren darían lugar a justificar nuevas represalias y captura de piezas". ${ }^{28}$ Acciones que muestran la gran "Resistencia

27 Ibídem, pág. 76.

28 Ibídem, págs. 110-112. 
Toba" de los años finales del siglo XVIII y primeros del XIX, ${ }^{29}$ negándose los orígenes y causas tupamaristas y mostrándose como actores principales a los criollos y mestizos pobres: "fueron paradójicamente los españoles, criollos y mestizos pobres quienes en un intento de subvertir un sistema colonial perverso, involucraron a un minúsculo grupo de desilusionados tobas y "salvajes e infieles" matacos; cuya presencia en las filas rebeldes fue la que proyectó y perfiló la figura, acción y nombre de Túpac Amaru II en los tumultos jujeños de 1781". ${ }^{30}$

Los motivos que llevan a los indígenas del Chaco a sumarse a la sublevación fueron la "natural disposición guerrera" chaqueña y el deseo de "venganza" derivado de la implantación de los fuertes, de la reducción y sobre todo de la Hacienda colonial. Por todo esto es que la rebelión se trató sólo de un episodio más en la larga duración de "resistencia chaqueña" que tiene antecedentes en los contactos prehispánicos e incas en el borde oriental de la Quebrada de Humahuaca, que se inició desde el mismo momento de la fundación de la ciudad de Jujuy en 1593, se acentúa en el siglo XVII, y continúa en el siglo XVIII, hasta la definitiva ocupación del Chaco en la modernización azucarera de 1884-1911. ${ }^{31}$

No hay mucha diferencia entre esta hipótesis y la primera en cuanto a la documentación utilizada para realizar las observaciones pertinentes. Al igual que en la anterior, se apela a las crónicas misioneras e informes de viajeros y colonizadores de finales del XVIII reproducidos por De Angelis, ${ }^{32}$ y también se considera el estudio de Acevedo como fuente de datos empíricos (especialmente el trabajo de Sánchez, que tiene en cuenta las referencias documentales de las notas al pie de página). En el estudio de Gullón Abao se utilizan fondos del Archivo Histórico de Jujuy, informes de visitas, planes de conquista del Chaco y documentación militar y colonizadora de los archivos históricos de Tucumán, Salta y General de Indias. Lo que sí incorpora como nueva fuente de esta hipótesis son expedientes de la Sala IX del Archivo General de la Nación Argentina, referentes a la

29 Ibídem, pág. 121.

30 Ibídem, pág. 135 y repetido en págs. 148-149.

31 Ibídem, pág. 148.

32 "Documentos para la historia...", págs. 343-521. Fernández Cornejo, Juan Adrián [1780]: "Diario de la primera expedición al Chaco emprendida en 1780", en De Angelis Pedro, Colección de obras y documentos .... Jolís, José [1789]: Ensayo sobre la Historia Natural del Gran Chaco, Reedición de la Universidad Nacional del Nordeste, Resistencia, 1972. Lozano, Pedro [1733]: Descripción Corográfica del Gran Chaco Gualamba, Universidad Nacional de Tucumán (Primera edición: 1941), Tucumán, 1989. 
actuación de los curas doctrineros franciscanos de San Ignacio de las décadas de 1790 y 1810 .

Donde se puede apreciar la diferencia entre esta hipótesis y la primera es en las teorías presupuestas: estos textos tienen en cuenta la perspectiva teórica de que los campesinos son continuos generadores de acciones políticas, aun en los períodos de aparente tranquilidad, cuando en realidad lo que hacen es acomodarse de la forma más exitosa posible. ${ }^{33}$ Idea tomada de los estudios de las rebeliones andinas que sostienen como "explicación alternativa respecto de la insurrección en el período colonial tardío, requiere que observemos seriamente la evolución de los patrones preexistentes de "adaptación en resistencia" (resistant adaptation), que implicaban una acción política innovadora de los campesinos para tratar de comprometer al Estado". ${ }^{34}$

Mientras que esa teoría presupuesta de la "adaptación en resistencia" corresponde exclusivamente a la segunda hipótesis, comparte con la primera la teoría presupuesta de Clastres del "ethos bélico" de las poblaciones primitivas, ${ }^{35}$ que da lugar al estudio de las relaciones sociales en la frontera tucumana del Chaco en el período colonial con la idea de una forma de ser de los indígenas "naturalmente" guerrera y belicosa, "resistente" por lo tanto a cualquier conquista, idea utilizada para caracterizar históricamente este período de la Colonia y al espacio de la frontera tucumana como una "frontera de guerra" ${ }^{36}$ La teoría acerca de la naturaleza violenta y guerrera de las sociedades indígenas del Chaco genera la idea de un estado de "guerra de frontera" como configuradora de la realidad social del Tucumán, ${ }^{37}$ compuesta por una plebe subalterna, díscola y

33 Sánchez Bramdam: Se hace camino..., pág. 18.

34 Stern, Steve J.: "Nuevas aproximaciones al estudio de la conciencia y las rebeliones campesinas: las implicaciones de la experiencia andina”, en Stern, Steve J. (comp.): Resistencia, rebelión y conciencia campesina en los Andes, siglos XVIII al XX, Instituto de Estudios Peruanos, Lima, 1990, págs. 32-33.

35 Clastres, Pierre: Arqueología de la violencia: la guerra en las sociedades primitivas, Fondo de Cultura Económica, Buenos Aires, 2004, que también se ha tenido en cuenta para el estudio de la vecina oriental y fronteriza cordillera chiriguana: Saignes, Thierry: AVA Y KARAY. Ensayos sobre la frontera Chiriguana (siglos XVI-XX), HISBOL, La Paz, 1990. Del mismo autor: Historia del pueblo chiriguano, IFEA-Plural Editores, La Paz, 2007.

36 Vitar, Beatriz: Tucumán y el Chaco en el siglo XVIII: milicia, jesuitas y fronteras, Universidad Complutense de Madrid, Madrid, 1988. De la misma autora: Guerra y misiones en la frontera chaqueña del Tucumán (1700-1767), Consejo Superior de Investigaciones Científicas, Madrid, 1997.

37 Garavaglia, Juan Carlos: "La guerra en el Tucumán colonial: sociedad y economía en un área de frontera (1660-1760)”, HISLA, IV, Lima, 1984, págs. 21-34. 
violenta y, especialmente, por indígenas violentos y guerreros. Teorías presupuestas que formulan la hipótesis fundamental de la "adaptación en resistencia", y que dan lugar a las ideas derivadas de que los fuertes, reducciones y haciendas son las instituciones que vertebran las relaciones sociales en la frontera, cuya existencia es reconocida y destacada por las fuentes, y su poder de dominación variable de acuerdo a la región y períodos por los que pasa la "guerra de frontera", pero sin duda es "dominante", tanto para las poblaciones "criollas" y "mestizas pobres" como para las poblaciones indígenas. Además de que este tipo de dominación es la que determina la forma de la "resistencia" en la frontera del Chaco de Jujuy: fugas de las reducciones, ataques esporádicos, huida de las haciendas, complicidad de los soldados con indígenas y mestizos pobres de la frontera, y violencia "vengativa" de los indígenas.

\section{Conclusión}

Los estudios sobre la rebelión indígena toba de 1781 en la frontera del Chaco de Jujuy disienten en cuanto a las causas pero concuerdan en que la expansión militar y colonizadora de las ciudades tucumanas al Chaco y la belicosidad de los indígenas chaqueños (especialmente en esta parte de la frontera de los tobas) son los factores determinantes en la configuración de esa "frontera de guerra". También coinciden en que la fórmula relativamente fracasada de las "Repúblicas" de españoles e indígenas es la que da lugar a la conformación de la "plebe" urbana y rural especialmente segregada, marginada, explotada, dominada y revoltosa, y que en concreto en la frontera del Chaco, es propensa a rebelarse contra esa situación. Finalmente argumentan que la resistencia indígena en la frontera es determinante en la nueva organización regional administrativa de las Intendencias y, según las dos hipótesis, no es casual que inmediatamente después de los sucesos rebeldes de 1781 se cree la Intendencia de Salta del Tucumán, con jurisdicción sobre gran parte de la frontera tucumana del Chaco. También se señala que el liderazgo criollo en esa rebelión tiene que ver con que la barbarie, salvajismo y concepción de vida "trágica" y belicosa de los indígenas no les permite encabezar el movimiento, o bien con que la idea de que "no obstante estos líderes consolidados durante el proceso de negociación, una vez reducido el grupo, pasaban en cierta medida a convertirse en figuras dependientes de los misioneros y capataces de haciendas, en el marco de 
una progresiva desintegración de la vida reduccional y de inserción en la sociedad colonial". ${ }^{38}$

Un problema no considerado al desarrollar la historia de la rebelión toba de 1781 es la cuestión del mercado de trabajo de las ciudades del Tucumán en la frontera chaqueña durante la segunda mitad del siglo XVIII. El avance colonizador, por medio de la conjunción de haciendas y reducciones resguardadas por fuertes, se desarrolla de manera acelerada desde la implementación de las políticas asistencialistas en el Chaco, ${ }^{39}$ hasta dar lugar a un mercado laboral relacionado con la producción mercantilista que corre a tono con el crecimiento económico y el auge del intercambio con las ciudades mineras y orientales bajo la jurisdicción de la Audiencia de Charcas. ${ }^{40}$ Así, las fronteras chaqueñas del Tucumán ven surgir en Jujuy haciendas azucareras con mano de obra principalmente indígena semirreducida y no reducida con el auxilio y control de la soldada de los fuertes, ${ }^{41}$ en Salta se revalorizan las mercedes de tierras y se transforman en propiedades disputadas ${ }^{42}$ y en el Tucumán la opción productiva de los cañaverales azucareros incorpora mano de obra mestiza y criolla de otros distritos y de la ciudad. ${ }^{43}$ Se constituye el mercado laboral que se vincula con las distintas formas de coerción económicas y extraeconómicas ejercidas sobre la sociedad fronteriza compuesta de esclavos, trabajadores mulatos y pardos

38 Vitar, Beatriz: "Algunas notas sobre la figura de los líderes chaqueños en las postrimerías del siglo XVIII”, en Teruel, A., Lacarrieu, M. y Jerez, O (comps.): Fronteras, ciudades y Estado, Jujuy, 2001, págs. 21-44.

39 Santamaría, Daniel: "Paz y asistencialismo vs. guerra y esclavitud. La política reformista del gobernador Gerónimo de Matorras en el Chaco Centro-Occidental, 1769-1775", Folia Histórica del Nordeste, 14, Resistencia, 1999, págs. 7-31.

40 Palomeque, Silvia: "La circulación mercantil en las provincias del interior, 1800-1810," Anuario del IEHS, 4, Tandil, 1989, págs.131-210. Assadourian, Carlos Sempat y Palomeque, Silvia: "Las relaciones mercantiles de Córdoba (1800-1830). Desarticulación y desmonetización del mercado interno colonial en el nacimiento del espacio económico nacional," en Irigoin, María Alejandra y Schmit, Roberto (editores): La desintegración de la economía regional. Comercio y moneda en el interior del espacio colonial (1800-1860), Biblos, Buenos Aires, 2003, págs. 151-225.

41 Cruz, Enrique N.: "Propiedad, producción y mano de obra en el piedemonte surandino. Las haciendas de Zegada en los valles orientales de Jujuy, fines de la colonia", Boletín Fuentes. América Latina en la Historia Económica, 16, México, 2001, págs. 105-121.

42 Mata de López, Sara, "Valorización de las propiedades agrarias y dinámica de las transacciones de tierras en Salta a fines del período colonial”, Boletín del Instituto de Historia Argentina y Americana, Dr. Emilio Ravignani, 3. ${ }^{\circ}$ serie, 1er. semestre de 1999, № 19, págs. 7-34. De la misma autora: Tierra y poder en Salta. El Noroeste Argentino en vísperas de la independencia, Diputación de Sevilla, Sevilla, 2000.

43 Gullón Abao, Alberto, "La mano de obra indígena en la frontera Este del Tucumán: trapiches y cañaverales", en El Noroeste Argentino como región histórica. Integración y desintegración regional. Estudio del país interior, Proyecto NOA, 2, Junta de Andalucía, Sevilla, 1992, págs. 35-48. 
relativamente libres, criollos y españoles vinculados o desvinculados a la "casa" de un peninsular o criollo ricos, indígenas tobas reducidos o semirreducidos, indígenas wichies semirreducidos o no reducidos, soldados partidarios y soldados presidiarios, algunos prisioneros y otros contratados por "plaza". ${ }^{44}$

Respecto de la rebelión toba como ejemplo de sublevación en pleno período colonial en espacios fronterizos a las ciudades tucumanas del Chaco se opina que es menester reconsiderar que la misma tiene que ver con la visión de "espasmos revolucionarios" 45 de castas indolentes, plebes urbanas mestizas e hispanizadas díscolas, e indígenas particularmente violentos, porque ello implicaría reconocer el carácter periférico y marginal de las sociedades de la frontera del Chaco y sus conductas como respuestas a estímulos, cuando en realidad se trata de ajustes locales, resueltos de manera más o menos violenta, de situaciones de sujeción y acomodación laboral. Por otro lado, se reconoce la utilidad de la idea de "la adaptación en resistencia", que no sólo ha contribuido a precisar las motivaciones, ideologías, duración y real extensión social y espacial de la "gran rebelión andina" ${ }^{46}$ sino que ha permitido volver a examinar en las causas locales y el propio desarrollo de las sociedades indígenas, las causas de la rebelión con-

44 Distando mucho de corresponder a la situación capitalista: "La libertad del obrero como vendedor de su fuerza de trabajo es esencial y marca la aparición de toda una época en el proceso de producción social. Eso es lo que caracteriza la época capitalista, que la fuerza de trabajo asume para el propio obrero, la forma de una mercancía que le pertenece y su trabajo asume la forma de trabajo asalariado". Marx, Carlos: El Capital. Crítica de la economía política, tomo I, FCE, México, 2000, pág. 121. Recién a fines del siglo XIX se constituye en esta parte del Chaco un mercado laboral capitalista con la reducción violenta de la mano de obra indígena en el marco del Estado Nacional Argentino y se modernizará la producción azucarera con la introducción de capitales y la mecanización. Campi, Daniel: "El noroeste argentino y el modelo agroexportador, 1870-1914. Reestructuración regional y producción azucarera”, en Lagos, M. (coord.): Jujuy en la Historia, Avances de investigación II, Universidad Nacional de Jujuy, Jujuy, 1995, págs. 143-171. Lagos, M., Teruel de Lagos, A., y Conti, V.: Mano de Obra Indígena en los Ingenios de Jujuy a principios de Siglo, Centro Editor de América Latina, Buenos Aires, 1988.

45 Sobre una crítica a la visión espasmódica de las revueltas populares preindustriales y la propuesta de reemplazo por una concepción de la "economía moral de la multitud", véase Thompson, Edgard: "La economía "moral" de la multitud en la Inglaterra del siglo XVIII," en Thompson, Edgard (ed.): Tradición, revuelta y conciencia de clase. Estudios sobre la crisis de la sociedad preindustrial, Crítica, Barcelona, 1984, págs. 62-134. Para una aplicación del concepto a las rebeliones indígenas coloniales: Stavig, Ward: "Ethnic conflict, moral economy, and population in rural Cuzco on the eve of the Thupa Amaro II rebellion", Hispanic American Historical Review, vol. 68, n. ${ }^{\circ}$ 4, 1988, págs. 237-270.

46 Walker, Charles (comp.): Entre la retórica y la insurgencia: Las ideas y los movimientos sociales en los Andes, siglo XVIII, Centro de Estudios Regionales Andinos Bartolomé de las Casas, Cusco, 1995. O’ Phelan Godoy, Scarlett: La gran rebelión de los Andes: De Tupac Amaru a Tupac Catari, Centro de Estudios Regionales Andinos Bartolomé de las Casas, Cusco, 1995. 
tra el sistema colonial de dominación y sus propias contradicciones. ${ }^{47}$ Así, se considera que en los conflictos que involucren a esas sociedades indígenas en las fronteras urbanas del Chaco en el Tucumán desde 1750, puede también ser de utilidad empezar a manejar ideas como las de "acomodación", "consenso", "acuerdo" y "sumisión", antes o mejor dicho exclusivamente, que las de resistencia violenta, cautiverio, esclavitud y guerra; en primer lugar porque la frontera chaqueña en este período ya es poco "de guerra" y se trata más de una "nueva sociedad de frontera" ${ }^{48}$ y debe menos, en su definitiva configuración capitalista del siglo XIX, a la dominación y explotación hispánica, y más a las conductas indígenas calificadas con dichas ideas, y porque en las situaciones de dominación colonial, como las que pone en evidencia la misma rebelión, la acomodación y la sumisión son sólo dos etapas circunstanciales en el ciclo de resistencia de las sociedades sometidas y dominadas. ${ }^{49}$

Recibido el 16 de abril de 2007 Aceptado el 29 de octubre 2007

47 Serulnikov, Sergio: Conflictos sociales e insurrección en el mundo colonial andino. El norte de Potosí en el siglo XVIII, FCE, Buenos Aires, 2006.

48 Cruz, Enrique N.: "La nueva sociedad de frontera. Los grupos sociales en la frontera de San Ignacio de Ledesma, Chaco occidental, finales del siglo XVIII", Anuario de Estudios Americanos, LVIII-1, Sevilla, 2001, págs. 135-160.

49 Hobsbawm, Eric J.: Rebeldes primitivos. Estudios sobre las formas arcaicas de los movimientos sociales en los siglos XIX y XX, Editorial Crítica, Barcelona, 2001. Rudé, George: La multitud en la historia. Estudio de los disturbios populares en Francia e Inglaterra 1730-1848, Siglo XXI Editores, Buenos Aires, 1971. Scout, C. James: Los dominados y el arte de la resistencia. Discursos ocultos, Ediciones Era, México, 2000. 